\title{
パワーアシストシステムにおける脳波を用いた 筋電推定手法の提案
}

吉岡 将孝 ${ }^{* 1}$, 吉川裕一郎 ${ }^{* 2}$, 上本 和広 ${ }^{* 2}$, 梁 宏博 ${ }^{* 2}$, 朱 赤 ${ }^{* 1, * 2}$

\section{EMG estimation from EEG for constructing a power assistance system}

\author{
Masataka YOSHIOKA ${ }^{* 1}$, Yuichiro YOSHIKAWA ${ }^{* 2}$, Kazuhiro UEMOTO $^{* 2}$, Hongbo LIANG ${ }^{* 2}$ \\ and Chi $\mathrm{ZHU}^{* 1, * 2}$ \\ ${ }^{* 1}$ Department of Environment and Life Engineering, Graduate School of Engineering, Maebashi Institute of Technology \\ 460-1 Kamisadori-cho, Maebashi-shi, Gunma 371-0816, Japan \\ ${ }^{* 2}$ Department of Systems Life Engineering, Graduate School of Engineering, Maebashi Institute of Technology \\ 460-1 Kamisadori-cho, Maebashi-shi, Gunma 371-0816, Japan
}

Received: 26 April 2016; Revised: 2 September 2016; Accepted: 26 January 2017

\begin{abstract}
In this paper, aiming to estimate force/torque information from brain activity to help and support the daily lives of human beings, we estimate the human muscular activity from EEG (Electroencephalogram) by PCA (Principal Component Analysis) and RLS (Recursive Least Squares). EEG and EMG (Electromyogram) are measured when a subject is flexing and extending his arm, and their linear model is established by PCA. Then, this linear model between EEG and EMG is updated by the angle, the angular velocity and the angular acceleration of the robot arm. Finally, EMG is estimated from EEG using the updated model. The results show that the estimation of EMG from EEG is possible, and using EEG support human's activities has a great potential.
\end{abstract}

Key words : Brain-machine Interface, EEG, EMG, PCA, RLS, Estimation

1. 緒言

厚生労働省の 5 年ごとの調査によると平成 23 年の身体障害者数は 386 万人で， 50 人に 1 人が体に障害を持っ ており (厚生労働省社会・援護局障害保健福祉部, 2013)，身体障害者のサポートが急務となっています．近年，体 を動かすことが出来なくなった身体障害者に対して, 脳から読み取った情報を用いてコミュニケーションツール やロボットを操作する Brain-Machine Interface (BMI) 技術の開発が進められている (Wolpawa et al., 2002) . また， 障害者の増加に伴い, 介護者の負担も増加している . 介護などの作業従事者のサポートとして , 外骨格ロボット によるパワーアシスト装置の開発が進められている (Herr, 2009)(Sankai, 2011)(Kiguchi and Hayashi, 2012)(Murray et al., 2015) . これまでの外骨格パワーアシスト装置を操作する信号は力/トルクセンサや筋電位センサから取得さ れているのが主流であったが, 身体障害者では光の信号となる力や筋電位を十分に発生させることは困難である ため，外骨格パワーアシストを行うことが出来ない．乥こで，身体障害者でも外骨格ロボットを操作できるよう に，BMI 技術を用いて脳から外骨格ロボットの制御信号を生成する試みが行われている (Presacco et al., 2011) .

このような BMI を用いた外骨格ロボットによるパワーアシストを実現するためには, 脳から得られる信号か ら使用者の運動意図や動きを推定する必要がある．关の手法として，機能的磁気共鳴画像 (functional magnetic

\footnotetext{
No.16-00195 [DOI:10.1299/transjsme.16-00195], J-STAGE Advance Publication date: 3 February, 2017

*1 正員, 前橋工科大学大学院環境生命工学専攻（干371-0816 群馬県前橋市上佐鳥町 460-1）

$*_{2}$ 前橋工科大学大学院システム生体工学専攻

E-mail of corresponding author: yoshioka_g@maebashi-it.ac.jp
} 
resonance imaging, fMRI) による脳内の活性部位の計測データを使用して筋肉の活動レベルを推定する研究が行わ れている (Birbaumer and Cohen, 2007)(Buch et al., 2008). fMRI は空間分解能が高く , 脳の内部の活動を観測する ことが出来るが , 装置が大型であり，コストがかかるという面で日常生活の支援する BMI の構築は難しい (Broetz et al., 2010) . 一方 , 脳内に電極を挿入し神経活動を直接計測すること手法や, 脳表面から電位変動を計測する手 法の侵襲型 BMI を用いた推定も行われている (Schalk et al., 2007)(Hochberg et al., 2012)(Nakanishi et al., 2014) . 侵 襲型 BMI は脳の神経活動を高い精度で観測することが出来るが，手術によって電極を取り付けるため，使用者の 負担は大きい . 光こで, 非侵襲で計測する手法の脳波 (Electroencephalogram, EEG) が BMI によるパワーアシスト システムを構築するのに適していると考えられる．

脳波は頭皮上の体積伝導によって発生した脳活動の電位変化を計測するため時間分解能が高いというメリット を持つ一方で, 空間分解能は低いというデメリットが挙げられる. 弚のため, これまで脳波から運動意図を抽出す る BMI は, 運動野周辺から得られる脳波の周波数の变化により, 運動意図を判別し ON/OFF 信号やパターン動作 の生成が行なわれてきた .たとえば, 手先の装具の開閉や (Pfurtscheller et al., 2000), 指先の屈曲・伸展 (Shindo et al., 2011) , 下半身の外骨格ロボットによる歩行機能の回復 (Kilicarslan et al., 2013) を行う非侵襲型 BMI を実現し ている. 近年では, 脳波から得られる周波数スペクトルの変化と手先の位置や角度などの運動情報で線形モデル を作成し, 角度や筋電情報の推定が行われている. Bradberry らは, 脳波の低周波数領域 $(\sim 1 \mathrm{~Hz})$ と 3 次元空間 での指先の速度の関係を 3 次元の軸ごとに線形モデルで表わし, 脳波から各軸方向の速度を推定した (Bradberry et al., 2010) . この技術を活用し, Presacco らは脳波から人の歩行における角度と角速度の变化を推定した (Presacco et al., 2011) . このように運動情報の推定には脳波との線形モデルを用いられているが , 作成されたモデルは時系 列線形モデルとなっており，歩行などの周期性のある運動にしか適応できず，また，多くのパラメータが必要とな る.さらに,この手法では, タスクごとにパラメータを学習しており，学習したタスクと異なるタスクを行った場 合は再構成の精度が落ちる傾向がある. 兴のため, タスクに影響されない, パラメータの逐次更新方法を導入す る必要があると考えられる．

脳波と運動情報に関するパラメータを逐次更新を行うためには，動作時にモデル作成に使用した脳波と運動の 両方の情報を取得する必要がある . 健常者の場合では , カトルクセンサや筋電位センサなどの情報からモデルパ ラメータの更新を行う教師信号を得ることが出来る.しかし, 身体障害者では力や筋電を発生させることが出来 ないため, 教師信号を得られず逐次更新を行うことが出来ない，光こで，本研究では装着した外骨格ロボットの 駆動時に得られる角度や角速度から，教師信号を得ることでこの問題の解決をする．これにより，カ/ルクセン サや筋電位センサを使わず, 兴の代わりに障害者の脳波を利用して，これまで開発されてきた外骨格ロボットによ るパワーアシスト技術を組み合わせた BMI パワーアシストシステムの実現を目指す . このシステムを構築するこ とで，障害者は動かせなくなった体を外骨格ロボットで動かすことができ，障害者の自立支援，および介護者の 負担軽減につなげることが出来ると考えられる．このような人が外骨格ロボットなどの機械によって動かされる のではなく，脳から得られた運動情報を用いた外骨格ロボットによる人と機械が協調し合うパワーアシストはま だ実現出来ていない．

本稿では弚の第一歩として，健常者の脳波と筋電の関係性をモデル化し，光のモデルを用いて脳波から筋電の 推定を行う.さらに, 人間の肘関節を一次遅れ系の Admittance モデルとして, 健常者の肘の角度, 角速度, 角加 速度を用いて関節を駆動する筋電を推定し，この推定された筋電位を教師信号として脳波と筋電のモデルの更新 を行う．したがって，まず健常者の肘の屈伸運動を行った際の脳波と筋電を計測し，主成分分析による脳波-筋電 間の線形モデル作成と，逐次最小二乗法によるパラメータの逐次更新方法について述べる .さらに，本手法を用 いた脳波からの筋電推定実験を行い，脳波によるパワーアシスト時にパラメータの逐次更新が可能であることの 有効性を確認する .

\section{2. 脳波と筋電および関節ト ルクの関係}

人が運動をしようとする際，筋電を発生させ関節トルクを発揮することから，筋電には人間の運動情報が含まれ ていることは良く知られている(木塚他，2008).また，筋電は運動細胞に支配されており，この運動細胞は大脳の 運動野により制御されているため, 運動における脳の活動と筋電の発生には深い関係があると言える (Bashashati 


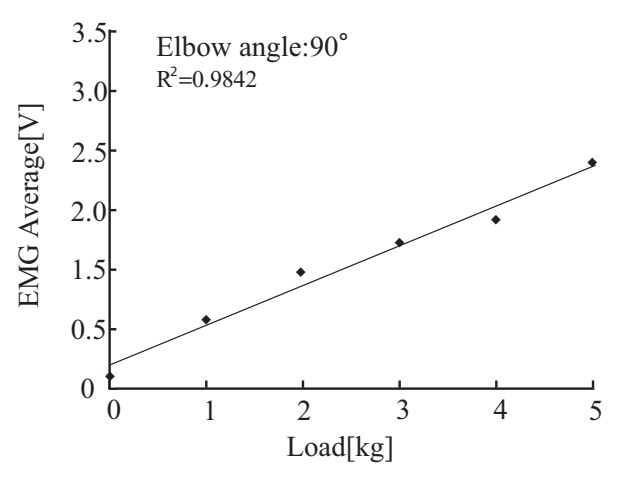

Fig. 1 Relationship of load to EMG signal

et al., 2007) . 脳波では人間が運動を行う時や運動を想像する時に，8-13Hzの帯域である $\mu$ 律動が抑制され，事象 関連脱同期 (ERD: Event-Related Desynchronization) が起こることが知られている (McFarland et al., 2000) (一條 , 高 橋，2009).さらに，1998 年に Halliday らによって行われた実験では，随意運動の際に 13-30Hz の及 波帯域の脳波 と筋電の間に有意な相関が見られることが明らかにされており (Halliday et al., 1998) , この相関は筋力調節の安定 性に関与していると考えられている．したがって，脳活動と筋電の関係は周波数領域におけるスペクトルの時間 変化から捉えることが可能であると考えられる. 本研究では, 運動時との関連が知られている $\mu$ 律動から $\beta$ 波ま での帯域に着目し，脳波-筋電間の線形モデルを作成するための入力とする .

また , 人の肘関節のトルクと筋電の関係性では, 人が重りを持った状態で肘を屈曲させた時の肘にかかるトル クと炎の負荷は比例する . 图 1 は重り $(0-5 \mathrm{~kg})$ を $90^{\circ}$ て維持した時の上腕二頭筋の筋電と負荷の関係を示してお り，近似線形関係となっている . 関節卜ルクは筋肉から発生する筋電の振幅と線形関係があることが分かっており (Clancy and Hogan, 1997), 肘関節は複数の筋肉の拮抗により関節卜ルクを発生しているが, 光のほとんどは主動 筋である上腕二頭筋の影響が大きい (Zhu et al., 2014) . したがって, 本研究では肘関節卜ルクと上腕二頭筋から計 測できる筋電の振幅 $v_{E M G}$ を一次の線形近似式で, 以下の式で表す .

$$
\tau=A v_{\text {emg }}-B
$$

ここで， $A$ は肘関節のトルクと筋電の関係を表す定数であり， $v_{e m g}$ は筋電の大きさ，B は無負荷時 (腕の自重を維 持する時) の筋電の大きさである . 本稿では筋電と肘関節のトルクの区別をせず, 肘関節卜ルクは式 (1)より筋電 から求める.

\section{3. 脳波からの筋電推定手法}

$3 \cdot 1$ 主成分分析を用いた脳波-筋電モデル生成

主成分分析とは，統計的データ解析や特徵抽出ならびにデータ圧縮によく用いられる手法である (Jolliffe, 2002) . 本研究では, この主成分分析を利用して脳波-筋電間の線形モデルを作成する .

今 , 入力信号として $N$ ヶ所の計測点より得られた $\mu$ 律動から $\beta$ 波帯域の脳波のパワースペクトル $x_{i}(\mathrm{i}=1,2, \ldots$, $\mathrm{N}), 1$ 所の計測点から得られた筋電 $v_{e m g}$ を与えるとする .この時の脳波と筋電間の主成分 $Z$ は次のように表わ される .

$$
Z=l_{1} x_{1}+l_{2} x_{2}+\cdots+l_{N} x_{N}+l_{\text {emg }} v_{\text {emg }}=\sum_{i=1}^{N} l_{i} x_{i}+l_{\text {emg }} v_{\text {emg }}
$$

ここで, $l_{i}(\mathrm{i}=1,2, . ., \mathrm{N})$ と $l_{\text {emg }}$ は $\mathrm{N}$ 個の脳波データと 1 個の筋電の入力データ間の分散共分散行列の最大固有値に 対応する固有べクトルである．これにより，主成分 $Z$ は固有べクトルを重み值とした脳波と筋電の線形結合で表 わすことが出来る. 式 (2) において, 筋電 $v_{e m g}$ について解くと,

$$
\hat{v}_{\text {emg }}=\frac{Z-\sum_{i=1}^{N} l_{i} x_{i}}{l_{\text {emg }}}
$$




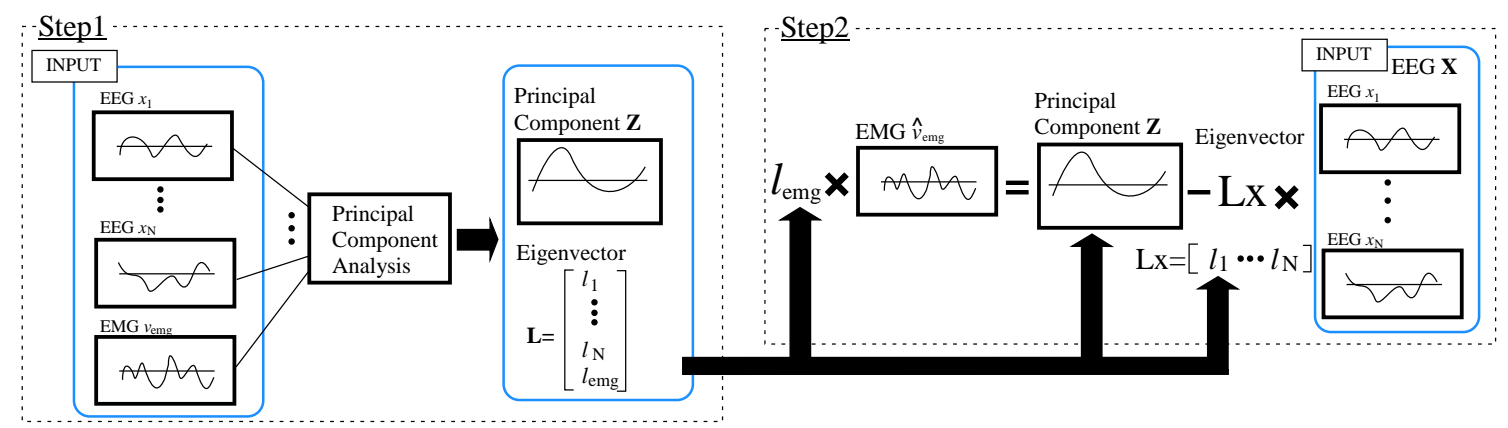

Fig. 2 The procedure for the modeling between EEG and EMG

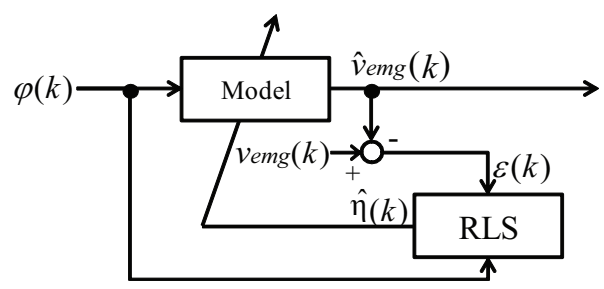

Fig. 3 Update of the model by the recursive least square technique

となり，式 (3) は推定筋電 $\hat{v}_{e m g}$ の求める式となる .ここで, 脳波データと筋電の主成分と固有ベクトルか既知の 場合， $N$ 個の脳波データから筋電 $\hat{v}_{e m g}$ を推定する線形モデルを得ることが出来る．

式 (3) を用いた脳波から筋電の推定手法の概要を図 2 に示す. まず, 同事象における複数点の脳波と 1 点の筋電 を入力信号として，主成分分析を用いて脳波 - 筋電間の線形モデルを作成する (図 2. Step 1) . 次に筋電を未知信 号として，新たに計測した脳波のみを入力信号とすることで，作成されたモデルと脳波から筋電を推定する (図 2. Step 2) . この手法を用いて脳波一筋電間の線形モデルで, 脳波から筋電を推定することにより，パワーアシス 卜装置への入力信号に用いることができる . 次に線形モデルのパラメータの更新について述べる .

\section{$3 \cdot 2$ 逐次最小二乗法によるパラメータの更新}

脳波一筋電間の線形モデルのパラメータを修正する手法として収束速度が速い, リアルタイム性が高い逐次最 小二乗法 (Recursive Least Square, RLS) (図 3) を導入する.まず，式 (3) による更新するパラメータ すると以下のようになる .

$$
\begin{aligned}
& \hat{v}_{\text {emg }}(k)=\boldsymbol{\phi}(k)^{T}(k) \hat{\boldsymbol{\eta}}(k-1) \\
& \boldsymbol{\phi}(k)=\left[\begin{array}{lll}
1 & x_{1}(k) \cdots x_{M}(k)
\end{array}\right]^{T} \\
& \hat{\boldsymbol{\eta}}(k-1)=\left[\frac{Z(k-1)}{l_{\hat{v_{e}} \mathrm{~g} g}(k-1)} \frac{-l_{1}(k-1)}{l_{\hat{v}}(k-1)} \cdots \frac{-l_{M}(k-1)}{l_{\hat{v}}(k-1)}\right]^{T}
\end{aligned}
$$

ここで $\boldsymbol{\phi}(k)$ は時刻 $k$ の入力， $\hat{\boldsymbol{\eta}}(k-1)$ は 1 つ前の時刻に推定されたパラメータを表す . 逐次最小二乗法では, 教 師データ $v_{e m g}$ と推定值 $\hat{v}_{e m g}$ の誤差 $\varepsilon(k)$ の 2 乗和を最小とするパラメータを逐次推定するように , ゲイン $\mathbf{G}(k)$ を 決定する . RLS のアルゴリズムは以下の式で表される (Haykin, 1996) .

$$
\begin{aligned}
& \hat{\boldsymbol{\eta}}(k)=\hat{\boldsymbol{\eta}}(k-1)+G(k) \boldsymbol{\varepsilon}(k) \\
& \boldsymbol{\varepsilon}(k)=v_{\text {emg }}(k)-\hat{v}_{\text {emg }}(k) \\
& \mathbf{G}(k)=\frac{\mathbf{P}(k-1) \boldsymbol{\phi}(k)}{\lambda+\boldsymbol{\phi}^{T}(k) \mathbf{P}(k-1) \boldsymbol{\phi}(k)} \\
& \mathbf{P}(k)=\frac{1}{\lambda}\{\mathbf{P}(k-1)-\boldsymbol{C}\} \\
& \boldsymbol{C}=\frac{\mathbf{P}(k-1) \boldsymbol{\phi}(k) \boldsymbol{\phi}^{T}(k) \mathbf{P}(k-1)}{\lambda+\boldsymbol{\phi}^{T}(k) \mathbf{P}(k-1) \boldsymbol{\phi}(k)}
\end{aligned}
$$




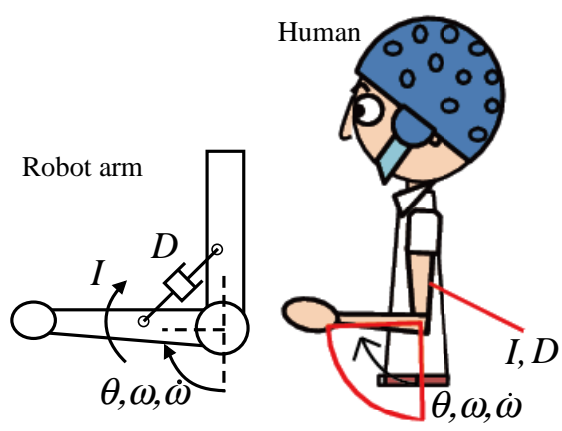

Fig. 4 Human's arm is assumed to be an admittance model

ここで, $\mathbf{P}$ は入力の分散共分散行列であり，初期値 $\mathbf{P}(0), \boldsymbol{\eta}(0)$ は PCA より算出する．また， $\lambda$ は可変忘却要素で ある. 本研究では, 入力信号を脳波, 出力信号を筋電としているため, 式 (3) の脳波 - 筋電モデルは時間と共に 動特性か変化する時変システムと考えることができる . 兴のため, 可変忘却要素 $\lambda$ を与えることで, 過去の入力信 号の影響を減らすことにより, 適応処理を実現する .この可変忘却要素 $\lambda$ は以下の式により定義される (Haykin, 1996) .

$$
\begin{aligned}
& \lambda(k)=\frac{1}{2}\left\{\mu(k)+\sqrt{\mu(k)^{2}+4 \xi(k)}\right\} \\
& \mu(k)=1-\xi(k)-\frac{\varepsilon^{2}(k)}{\boldsymbol{I}^{*}} \\
& \xi(k)=\phi^{T}(k) \mathbf{P}(k-1) \phi(k)
\end{aligned}
$$

ここで, $\boldsymbol{I}^{*}$ は，任意で指定可能なパラメータであり，推定の追従性と安定性を調節することが可能である．

\section{$3 \cdot 3$ パラメータ更新のための教師信号}

健常者や力は衰えているが筋電の生成が出来る人は直接実際の筋電を用いることができるため, 筋電の推定は 必要ない。しかし, 運動神経に障害を持つ筋電の生成が困難な障害者の場合, 教師データである筋電 $v_{e m g}(k)$ を用 いることは出来ないため, 前述の $<3 \cdot 1>,<3 \cdot 2>$ に述べた脳波から筋電信号を推定するため別の情報を用い て RLS で更新する必要がある，光こで, 本研究では人の腕を图 4 に示すような慣性モーメントとダンパーで構成 される Admittance モデルに近似し，人間の運動から関節の駆動トルクを推定し，乥の推定された駆動卜ルクを実 際の筋電として教師信号として利用する.

先行研究の拡張 Admittance 制御によるパワーアシスト理論 (Zhu et al., 2014) によると, パワーアシストは式 (1) の筋電 $v_{e m g}$ から計算された肘のトルク $\tau$ を用いて目標角速度 $\omega$, 目標角加速度 $\dot{\omega}$ を算出し, ロボットアームに与 えることで実現される .この時, 肘関節のトルクと目標角速度・角加速度の関係式は以下のように表すことがで きる .

$$
\begin{aligned}
& \tau-\tau_{0}=I \dot{\omega}+D \omega \\
& \tau_{0}=b \tau_{\text {max }} \sin \theta
\end{aligned}
$$

ここで, $\tau_{\max }$ は試行中に得られた肘の最大トルク,$I$ と $D$ は人間と外骨格ロボットの仮想慣性モーメントと仮想ダ ンピング係数である．また， $\tau_{0}$ は維持時のトルクを表わしており， $b$ は維持時のトルクと最大トルクの関係を表 す定数である . この維持時のトルク $\tau_{0}$ 内の係数 $b$ の決定に関しては, 先行研究の文献 (Zhu et al., 2014) を参考に

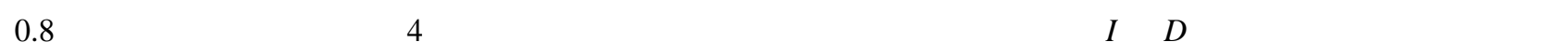
慣性モーメントとダンピング係数として入れ替えることにより，人間の肘関節を Admittance モデルとして見なし， パワーアシスト理論を弚のまま適用することができる．

脳波から筋電を推定するための処理手順を図 5 に示す．まず，脳波データ (EEG) は PCA を介して得られた脳 波-筋電モデルに代入され，推定筋電を得ることが出来る. 次に, RLS の教師信号の筋電 $v_{\text {emg }}$ は肘関節の角度・角 


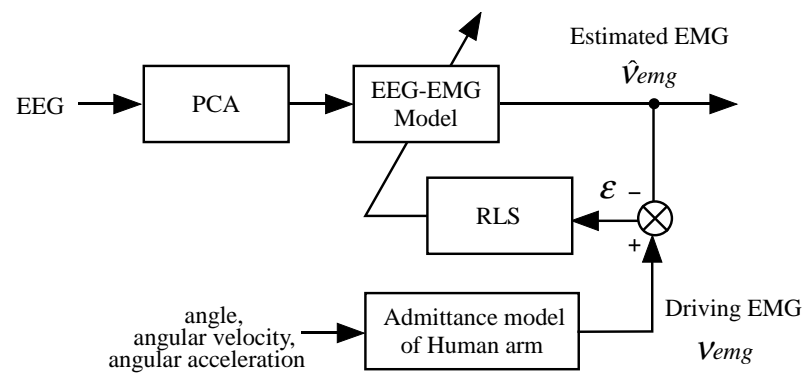

Fig. 5 A Flowchart for the estimating EMG, and the updating of parameters

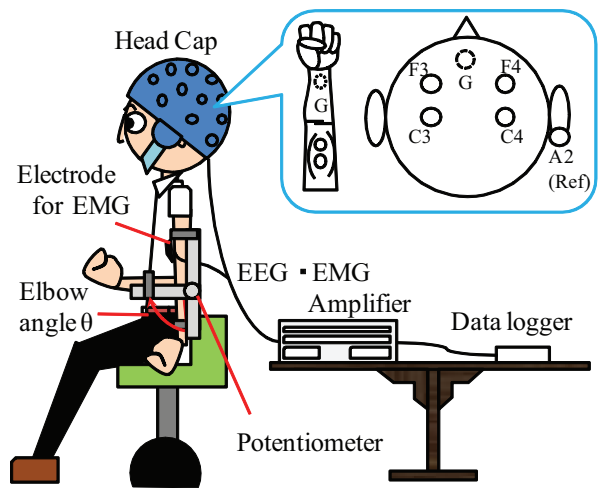

Fig. 6 Measurement environment

加速度・角加速度を用いて式 (1), 式 (15)-(16)より，

$$
v_{\text {emg }}=\frac{\tau_{0}+I \dot{\omega}+D \omega+B}{A}
$$

となる . 肘の関節角度 $\theta$ は , 肘に取り付けられたエンコーダまたはポテンショメータより得ることが可能である ため, $\theta$ から角速度 $\omega$, 角加速度 $\dot{\omega}$ の算出ができ, 筋電の推定が可能となる . この教師信号を RLS に与えること により, 脳波-筋電モデルの更新を行う .

\section{4. 脳波からの筋電推定の実験}

\section{$4 \cdot 1$ 脳波および筋電計測}

本実験はあらかじめ前橋工科大学のインフォームドコンセントにおける倫理委員会の了承の下で, 被験者を 20 代の健常な右利きの男性 3 名として, 被験者に対して実験内容を十分に説明し, 脳波・筋電計測の同意を得た . 被 験者は図 6 に示すように目を開けて椅子に座り，手を回外位の状態で重りを持ち，肩は床と垂直な状態で肘関節 の約 $90^{\circ}$ まで屈曲，屈曲状態での維持，および伸展運動を行う . また，被験者の左腕の肘関節角度をポテンショ メータを用いて計測し，全てのデータの記録にはデータロガーを用い，サンプリング周波数を $1000 \mathrm{~Hz}$ とした .

この実験では，被験者は屈曲伸展運動を 1 回行う場合と 2 回行う場合の 2 パターンの試行を行い, 音や光など の刺激による脳波への影響を無くすため，これらの運動は被験者の任意のタイミングで行った . 脳波計測点は国 際 10-20 法電極配置に基づき，運動に関連する脳の運動野付近の $\mathrm{C}_{3}, \mathrm{~F}_{3}, \mathrm{C}_{4}, \mathrm{~F}_{4}$ の 4 点（図 6) として，乥れ光 れ耳染 $\left(\mathrm{A}_{2}\right)$ との差動増幅を行った . また , アース電極は額とした . 同時に , 左腕の上腕二頭筋を計測点として筋 電計測を行い, 筋電のアース電極は左手首とした .

脳波と筋電の増幅アンプにはg.BSamp (g.tec 社) を使用し , バンドパスフィルタの通過帯域を 0.5-1000Hzに設 定し，50Hzのノッチフィルタに通した .さらに , 脳波の電極には g.LADYbird ( g.tec 社) のアクティブ電極を使 用した .アクティブ電極は, 電極側でインピーダンス変換アンプを内蔵することにより, 増幅アンプに直接つなげ るパッシブ電極比べて皮膚と電極間のインピーダンスの影響を無くし，アーティファクトを抑えることが出来る． このアクティブ電極で脳波を取得することにより，頭皮上の電極接触インピーダンスの影響や体を動かした際の コードの摇れによるノイズの混入を防いでいる .

\section{$4 \cdot 2$ 信号の処理手順}

信号の処理の流れを図 7 に示す. 本実験ではオフラインで筋電推定を行い, 計測した脳波 (Raw EEG) を 256 点の空幅 $(256 \mathrm{msec}), 50$ \%のオーバーラップで高速フーリエ変換 (FFT) を行い , 7-30Hz のパワースペクトルを算 出した .これにより，128msec ごとに各周波数帯域のパワースペクトルを得ることができ，周波数分離することで 体動などの影響で発生する低周波領域 (5Hz 以下) のノイズや生体アンプでの電源ノイズ $(50 \mathrm{~Hz})$ を分離するこ とが出来る.脳波は各計測点 $\left(\mathrm{C}_{3}, \mathrm{~F}_{3}, \mathrm{C}_{4}, \mathrm{~F}_{4}\right)$ の $\mu$ 波帯域 $(8-13 \mathrm{~Hz})$ と $\beta$ 波帯域 (13-30Hz) の低周波領域を含ん だ7-30Hzのパワースペクトルを入力信号とした . 


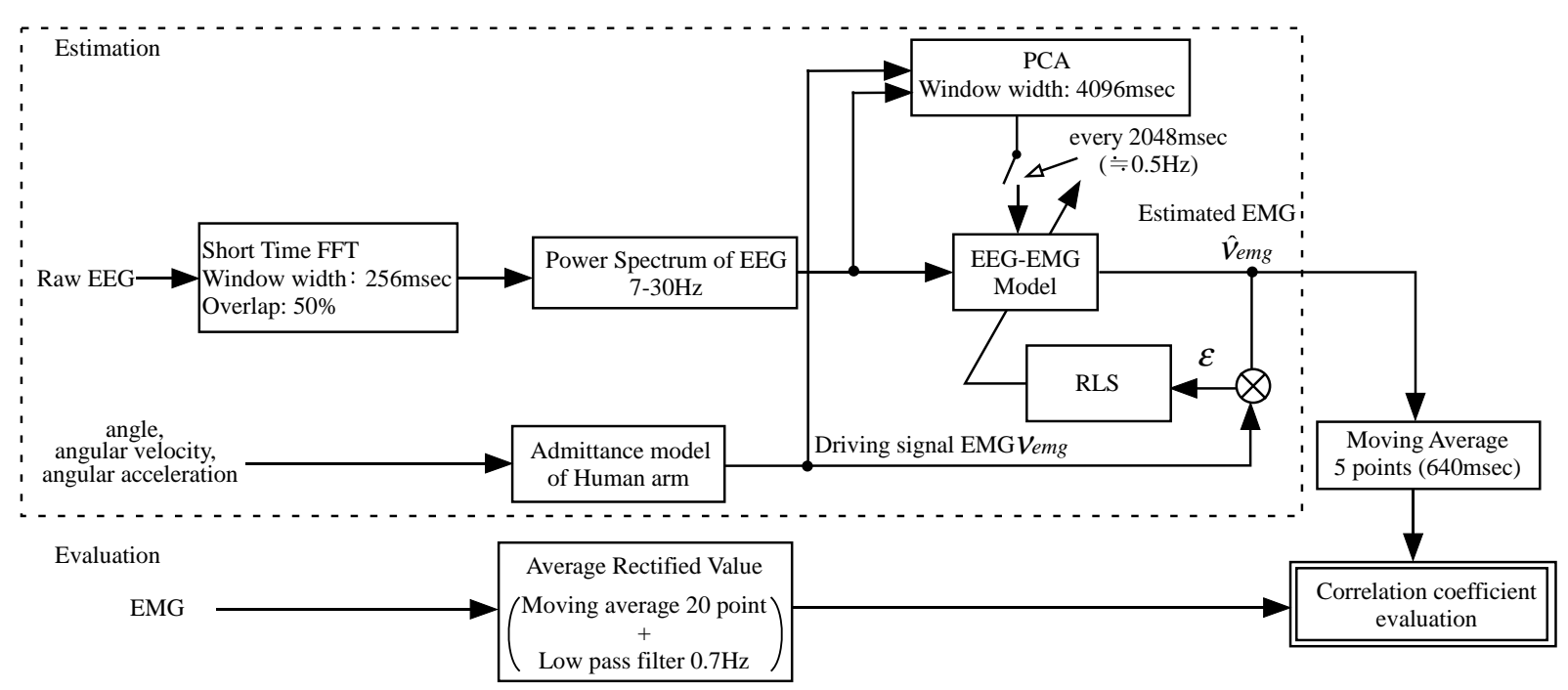

Fig. 7 Signal processing procedure

本実験では, 脳波パワースペクトルと肘関節の Admittance モデルから得られた推定筋電 $\hat{v}_{e m g}$ を用いて , PCA で 密幅 $4096 \mathrm{msec}$ の 50 \%のオーバーラップ $(\fallingdotseq 0.5 \mathrm{~Hz})$ に脳波-筋電モデルの生成を行う .ここで , モデルの生成の密 幅を $4096 \mathrm{msec}$ にするのは, 肘関節を伸ばした状態から $90^{\circ}$ 屈曲状態までの脳波と筋電および関節卜ルクの変化を モデルに反映させるためである . 次に, 入力信号の脳波と筋電は変化の特性が時変であると考えられるため, モ デルの更新が必要となる.今回，各計測点 $\left(\mathrm{C}_{3}, \mathrm{~F}_{3}, \mathrm{C}_{4}, \mathrm{~F}_{4}\right)$ のパワースペクトルから推定された筋電 $\hat{v}_{\text {emg }}$ と， 被験者の肘関節の角度から推定された筋電 $v_{e m g}$ と比較し，RLS を用いてパラメータを更新し，筋電を推定してい く.また，結果の比較のために計測された筋電 $v_{\text {emg }}$ は整流平滑化 $(20$ 点の移動平均 $+0.7 \mathrm{~Hz}$ の一次ローパスフィ ルタ) を行い, 推定された筋電 $\hat{v}_{e m g}$ もローパスフィルタ (5 点 (空幅 $640 \mathrm{msec}$ ) の移動平均) を用いて平滑化し， 弚の相関係数による評価を行う.

\section{$4 \cdot 3$ 推定結果および考察}

提案した手法を確認するため, 被験者 3 人での検証実験を行った . 被験者 A が 1 試行の肘の屈伸運動を行った 時の筋電推定結果を図 8 に示す.ここで, 実線 (青線) は計測された筋電, 破線 (赤線) は脳波から推定された筋 電を表わしている . 計測された筋電が大きく増加する瞬間から被験者 $\mathrm{A}$ は肘の屈曲運動 (Flexion) をし始め, 一定 時間の維持運動 (Keeping) を行った後, 筋電が大きく降下するタイミングに伸展運動 (Extension) をしている .こ の屈曲運動から伸展運動までの区間を運動状態 (Motion) とし，光れ以外の区間を安静状態 (Rest) とした .この 図から，推定された筋電は計測された筋電が大きくなると共に上がり，小さくなると下がっていることが分かり， 相関係数 $\mathrm{r}$ は 0.94 となった . また, 被験者 $\mathrm{A}$ はこの 1 試行の肘の屈伸運動を 10 試行行い, 弚の相関係数は平均 で 0.85 となった。

そとて, 図 9 に被験者 $\mathrm{A}$ の連続して 2 回の屈伸運動を 10 試行行った時の相関係数が最も高かった時の推定結果 を示す.このうち, 1 試行目の屈伸運動 (Motion) では相関係数は 0.79 となり, 2 回目では 0.88 と高くなった . 光 して, 2 回の屈曲運動と安静状態 (Rest) を含めた全体の計測筋電との相関係数は 0.89 であった . また，この 2 試 行の屈伸運動 10 試行の全体の相関係数の平均は 0.85 となった .

次に，図 10 に被験者 B が肘の屈伸運動を 1 回行った時の相関係数が最も高い推定結果を示す . この時の相関係 数は 0.83 であり, 6 試行の計測を行った時の計測筋電との相関係数の平均は 0.75 だった . また，図 11 は, 2 試行 の肘の屈伸運動を行った時の結果で, 1 試行目の屈伸運動 (Motion) の相関係数は 0.83 となり，2 試行目では 0.85 であることから， 1 試行目より 2 試行目の相関係数が上がっていることが分かる. そして, 2 回の屈曲運動と安静 状態 (Rest) を含めた全体の相関係数は 0.86 であった .さらに，これらの推定筋電の昇降は計測された筋電と同じ タイミングであることが分かる．また， 6 試行の計測を行った時の相関係数の平均は 0.79 であった .

次に, 被験者 $\mathrm{C}$ の実験結果について述べる.被験者 $\mathrm{C}$ では 8 試行分のデータを解析した. 光の結果, 肘の屈伸 


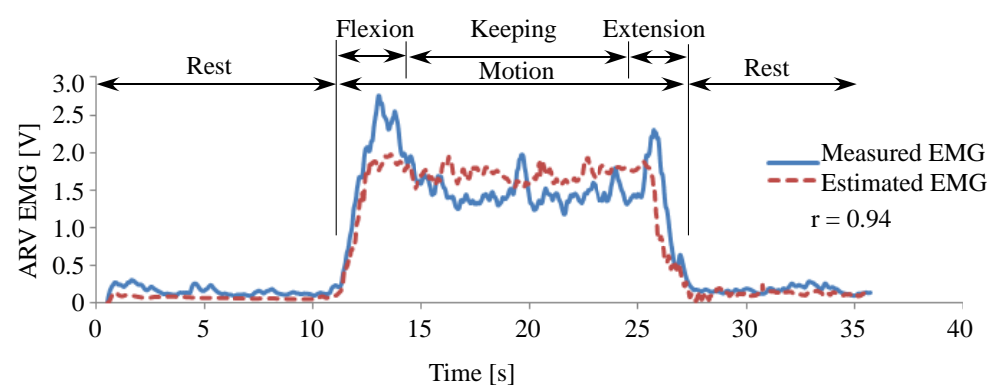

Fig. 8 Estimation results of once flexion and extension movements of Subject A

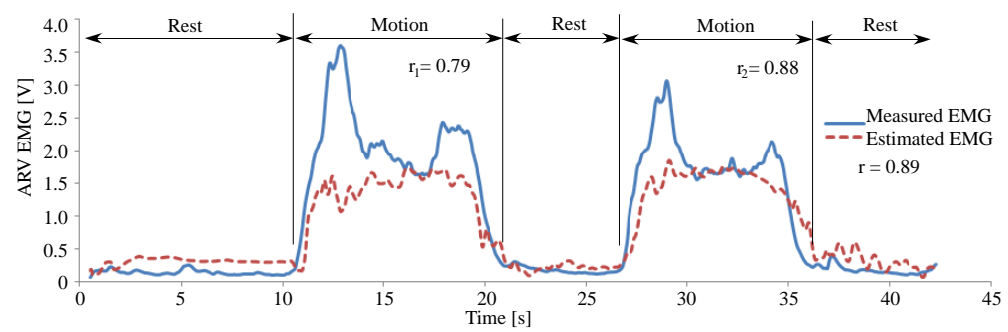

Fig. 9 Estimation result of twice flexion and extension movements of Subject A

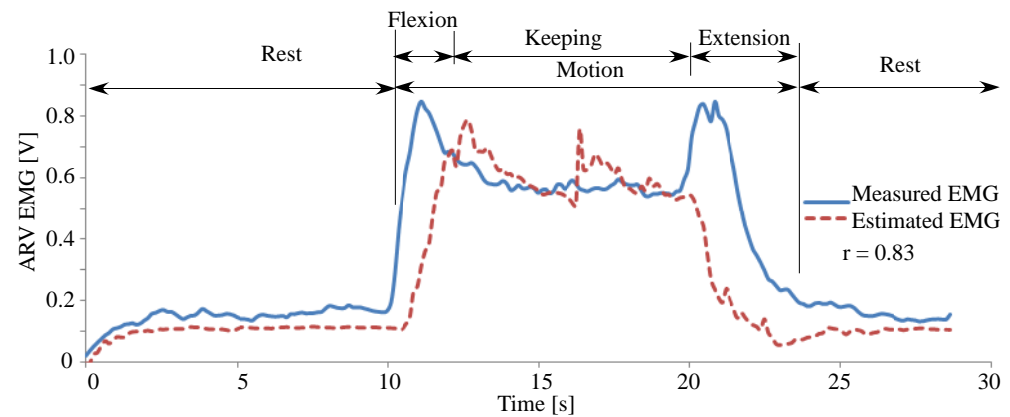

Fig. 10 Estimation result of once flexion and extension movements of Subject B

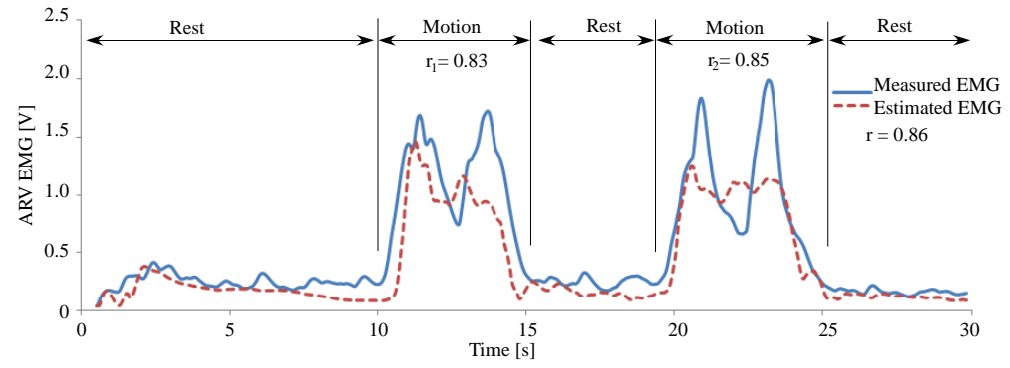

Fig. 11 Estimation result of twice flexion and extension movements of Subject B

が 1 試行の場合，相関係数の平均は 0.72 となり，最高で 0.80 であった . 兴の時の結果を図 12 に示す. また， 2 試 行連続屈伸した場合では, 1 試行目の相関係数は $0.55,2$ 試行目は 0.78 となり，ほかの被験者と同樣に 2 試行目の 相関係数が高いことがわかった . 兴の結果を図 13 に示す. 2 回の屈曲運動と安静状態 (Rest) を含めた全体の相関

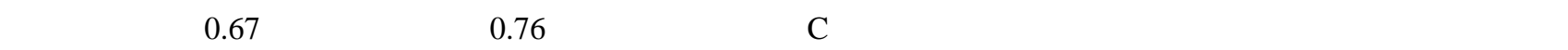
2 試行目の推定された筋電は計測された筋電とほぼ一致している.また, 筋電の変化が安定している時は, 推定筋 電も安定していることが見られた .

これらの結果を表 $1 に, 3$ 人の被験者の肘の屈曲・伸展運動時の脳波から筋電を推定した結果をまとめる．また， 推定の精度の数值評価には計測筋電の積分值 $S_{\text {emg }}$ と推定筋電の積分值 $S_{\text {estimate }}$ の差を計測筋電の積分值で次式の 


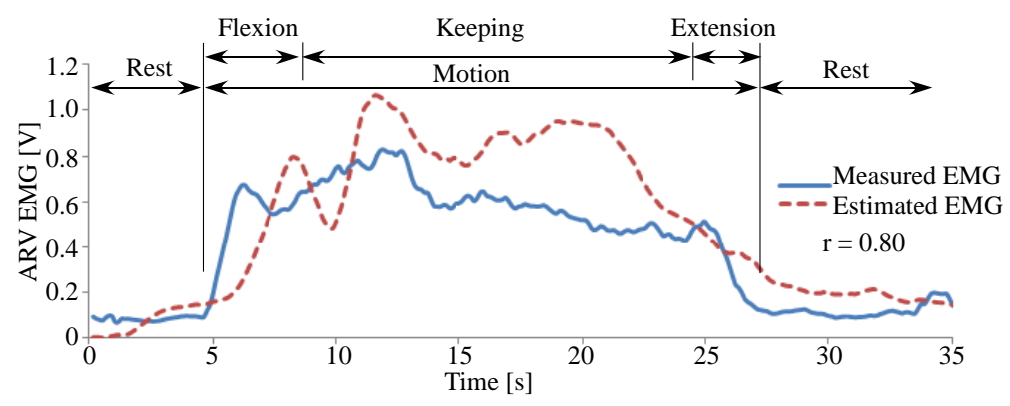

Fig. 12 Estimation result of once flexion and extension movements of Subject C

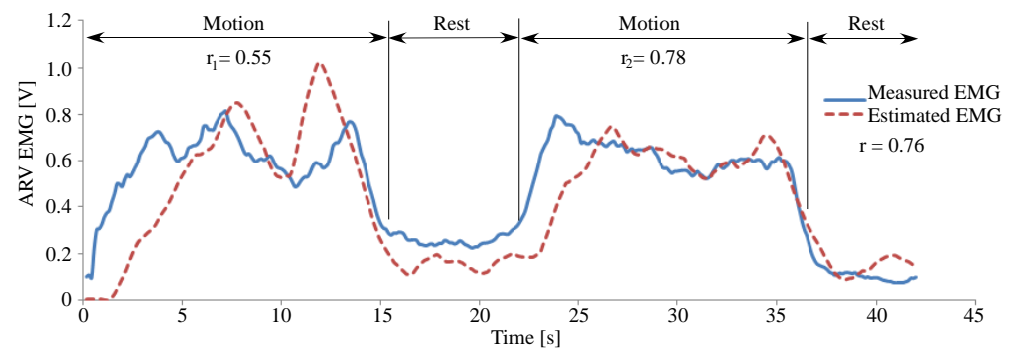

Fig. 13 Estimation result of twice flexion and extension movements of Subject C

Table 1 Correlation of coefficient and error between measured EMG and estimated EMG

\begin{tabular}{|c|c|c|c|c|}
\hline \multicolumn{2}{|c|}{} & Subject A & Subject B & Subject C \\
\hline \hline Once & Mean & 0.85 & 0.76 & 0.72 \\
Elbow f/e & $(\mathrm{SD})$ & $(0.04)$ & $(0.06)$ & $(0.08)$ \\
\cline { 2 - 5 } $\mathrm{R}$ & Max & 0.94 & 0.81 & 0.80 \\
\hline Error & Mean & 9.77 & 10.50 & 5.51 \\
{$[\%]$} & $(\mathrm{SD})$ & $(6.48)$ & $(6.36)$ & $(3.72)$ \\
\hline \hline Twice & Mean & 0.85 & 0.793 & 0.66 \\
Elbow f/e & $(\mathrm{SD})$ & $(0.04)$ & $(0.05)$ & $(0.08)$ \\
\cline { 2 - 5 } $\mathrm{R}$ & Max & 0.89 & 0.86 & 0.76 \\
\hline Error & Mean & 5.30 & 6.42 & 4.45 \\
{$[\%]$} & $(\mathrm{SD})$ & $(5.64)$ & $(2.41)$ & $(2.28)$ \\
\hline
\end{tabular}

ように割合を表わし，光の平均を算出した．

$$
\text { error }=\frac{\left|S_{\text {estimate }}-S_{\text {emg }}\right|}{S_{\text {emg }}} \times 100[\%]
$$

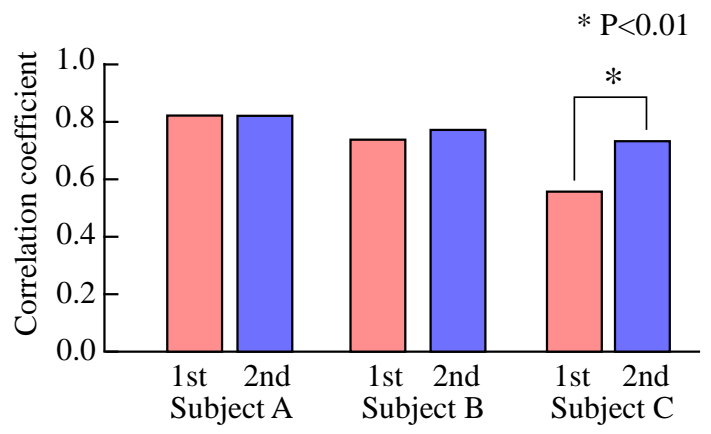

Fig. 14 Comparison of the correlation coefficient average of the first and the second trial during twice flexion and extension movements

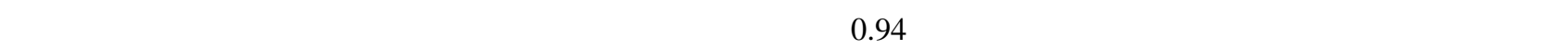
合の平均は被験者 $\mathrm{A}$ と C は 10 \%以下となり，被験者 B において平均值が最大の $10.5 \%$ となった . 本手法により， 安静状態からの屈曲, 屈曲状態の維持, 維持状態からの伸展と, 時間と共に状態か変わる場合でも, 推定可能で あり本手法の有効性が示されたと言える. 乥して, 図 14 に各被験者が 2 試行続けて行った時の 1 回目と 2 回目の

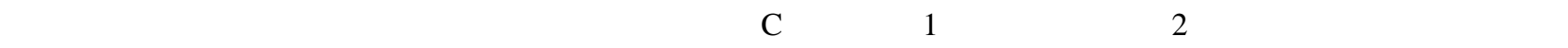
なっており，有意差が見られた .これは，計測筋電と推定筋電との誤差が时の角度・角加速度から得られた教師信 号に基づいた逐次最小二乗法によりパラメータの值が補正され，推定精度が向上したと考えられる．また，被験 者 $\mathrm{A}$ と B では 1 試行目および 2 試行目が光れ光れ推定精度が高かったため，パラメータの補正が小さかったと考 えられる。 


\section{5. まとめ 今後の展望}

本研究では, 脳波を用いて外骨格パワーアシスト装置を制御し, 障害者の自立支援を行うことを目標とし，本稿 では光の第一歩として, 脳活動と運動情報の線形モデルと学習手法を使用することで, 脳波からの筋電推定を試 みた . まず, 肘関節の屈曲運動時における $\mu$ 波および $\beta$ 波のパワースペクトルの変化を主成分分析を用いて，筋 電との線形モデルを作成した．光して，光の線形モデルを逐次最小二乗法で更新する際の教師信号として，肘の 角度, 角速度, 角加速度を用いた人の肘の Admittance モデルから推定された筋電を用いた . その結果, 脳波から 推定された筋電は計測された筋電との相関係数が最大 0.94 となり, 試行を増やすことで低い推定精度を向上させ る事ができ，脳波を用いたパワーアシストの有効性を示した．

今後, 個人差に対応するために, 可変忘却係数などのパラメータに評価関数を設けて個人差にも適応可能な制 御手法への拡張が必要である .さらに, 今回の実験は全てオフラインで行われたため, 実際に装着した際のアー ムからの力のフィードバックの影響を確認して, 推定誤差が生じた際のトルク・角度制限の安全性を考慮し, 今 後実機での検証を行う必要がある．また，被験者で作成された筋電-脳波の線形モデルが，ほかの被験者に適応で きるかの検討を行い，脳波による障害者のパワーアシストシステムを実現する．

\section{文献}

Bashashati, A., Fatourechi, M., Ward, R. K. and Birch, G. E., A survey of signal processing algorithms in brain-computer interfaces based on electrical brain signals, Journal Neural engineering, Vol.4 (2007), pp 32-57.

Birbaumer, N. and Cohen, L. G., Brain-computer interfaces: communication and restoration of movement in paralysis, Journal of Physiology, Vol.579, Issue 3 (2007), pp.621-636.

Bradberry, T. J., Gentili, R. J. and Contreras-Vidal, J. L., Reconstructing three-dimensional hand movements from noninvasive electroencephalographic signals, The Journal of Neuroscience, Vol. 30, No.9 (2010), pp.3432-3437.

Broetz, D., Braun, C., Weber, C., Soekadar, S. R., Caria, A. and Birbaumer, N., Combination of brain-computer interface training and goal-directed physical therapy in chronic stroke: a case report, Neurorehabil Neural Repair, Vol.24, No.7 (2010), pp.674-679.

Buch, E., Weber, C., Cohen, L. G., Braun, C., Dimyan, M. A., Ard, T., Mellinger, J., Caria, A., Soekadar, S., Fourkas, A. and Birbaumer, N., Think to move: a neuromagnetic brain-computer interface (BCI) system for chronic stroke, Stroke, Vol.39, No.3 (2008), pp.910-917.

Clancy, E. A. and Hogan, N., Relating agonist-antagonist electromyograms to joint torque during isometric, quasiisotonic, nonfatiguing contractions, IEEE Transactions on Biomedical Engineering, Vol.41, No.10 (1997), pp.10241028.

Halliday, D. M., Conway, B . A., Farmer, S. F. and Rosenberg, J. R., Using electroencephalography to study functional coupling between cortical activity and electromyograms during voluntary contractions in humans, Neuroscience Letters, Vol.241, Issue 1 (1998), pp.5-8.

Haykin, S., Adaptive filter theory, third ed., Upper Saddle River, NJ, Prentice-Hall(1996).

Herr, H., Exoskeletons and orthoses: classification, design challenges and future directions, Journal of NeuroEngineering and Rehabilitation, Vol.6, No.21 (2009), pp.1-9.

Hochberg, L. R., Bacher, D., Jarosiewicz , B., Masse, N. Y., Simeral, J. D., Vogel, J., Haddadin, S., Liu, J., Cash, S. S., van der Smagt, P. and Donoghue, J. P., Reach and grasp by people with tetraplegia using a neurally controlled robotic arm, Nature, Vol.485 (2012), pp.372-375.

一條貞雄，高橋系一，脳波判読に関する 101 章 第 2 版，医学書院 (2009).

厚生労働省社会・援護局障害保健福祉部, 平成 23 年生活のしづらさなどに関する調査 (全国在宅障害児・者等 実態調査) 結果, (2013) .

Jolliffe, I. T., Principal component analysis. 2nd ed., Springer (2002).

Kiguchi, K. and Hayashi, Y., An EMG-based control for an upper-limb power-assist exoskeleton robot IEEE Transactions on Systems, Man, and Cybernetics Part B: Cybernetics, Vol.42, No.4 (2012), pp.1064-1071.

木塚朝博，増田正，木竜徹，佐渡山亜兵，表面筋電図，バイオメカニズム学会 (編), 東京電機大学出版局 (2008). 
McFarland, D. J., Miner, L. A., Vaughan, T. M. and Wolpaw, J. R., Mu and beta rhythm topographies during motor imagery and actual movements, Journal of Cerebral Function and Dynamics Brain Topography, Vol.12, No.3 (2000), pp.177-186.

Murray, S. A., Ha, K. H., Hartigan, C. and Goldfarb, M., An assistive control approach for a lower-limb exoskeleton to facilitate recovery of walking following stroke, IEEE Transactions on Neural Systems and Rehabilitation Engineering, Vol.23, No. 3 (2015), pp.441-449.

Nakanishi, Y., Yanagisawa, T., Shin, D., Fukuma, R., Chen, C., Kambara, H., Yoshimura, N., Hirata, M., Yoshimine, T. and Koike, Y., Prediction of three-dimensional arm trajectories based on ECoG signals recorded from human sensorimotor cortex, PLoS ONE, Vol.8, Issue 8, e72085 (2014), pp.1-9.

Pfurtscheller, G., Guger, C., Müller, G., Krausz, G. and Neuper, C., Brain oscillations control hand orthosis in a tetraplegic, Neuroscience Letters, Vol.292, Issue 3 (2000), pp.211-214.

Presacco, A., Goodman, R., Forrester, L. and Contreras-Vidal, J. L., Neural decoding of treadmill walking from noninvasive electroencephalographic signals, Journal of Neurophysiol. Vol.106(2011), pp.1875-1887.

Sankai, Y., HAL: hybrid assistive limb based on cybernics, The 13th International Symposium Robotics Research, Vol.66 (2011), pp.25-34.

Schalk, G., Kubánek, J., Miller, K. J., Anderson, N. R., Leuthardt, E. C., Ojemann, J. G., Limbrick, D., Moran, D., Gerhard, L. A. and Wolpaw, J. R., Decoding two-dimensional movement trajectories using electrocorticographic signals in humans, Journal of Neural Engineering, Vol.4, No.3 (2007), pp.264-275.

Shindo, K., Kawashima, K., Ushiba, J., Ota, N., Ito, M., Ota, T., Kimura, A. and Liu, M., Effects of neurofeedback training with an electroencephalogram-based brain-computer interface for hand paralysis in patients with chronic stroke a preliminary case series study, Journal of Rehabilitation Medicine, Vol.43, Issue 10 (2011), pp.951-957.

Wolpawa, J. R., Birbaumer, N., McFarland, D. J., Pfurtscheller, G. and Vaughan, T. M., Brain computer interfaces for communication and control, Clinical Neurophysiology, Vol.113(2002), pp.767-791.

Zhu, C., Okada, Y., Yoshioka, M., Yamamoto, T., Yu, H., Yan, Y. and Duan, F., Power augmentation of upper extremity by using agonist electromyography signals only for extended admittance control, IEEJ Journal of Industry Applications, Vol.3, No.3 (2014), pp.260-269.

\section{References}

Bashashati, A., Fatourechi, M., Ward, R. K. and Birch, G. E., A survey of signal processing algorithms in brain-computer interfaces based on electrical brain signals, Journal Neural engineering, Vol.4 (2007), pp 32-57.

Birbaumer, N. and Cohen, L. G., Brain-computer interfaces: communication and restoration of movement in paralysis, Journal of Physiology, Vol.579, Issue 3 (2007), pp.621-636.

Bradberry, T. J., Gentili, R. J. and Contreras-Vidal, J. L., Reconstructing three-dimensional hand movements from noninvasive electroencephalographic signals, The Journal of Neuroscience, Vol. 30, No.9 (2010), pp.3432-3437.

Broetz, D., Braun, C., Weber, C., Soekadar, S. R., Caria, A. and Birbaumer, N., Combination of brain-computer interface training and goal-directed physical therapy in chronic stroke: a case report, Neurorehabil Neural Repair, Vol.24, No.7 (2010), pp.674-679.

Buch, E., Weber, C., Cohen, L. G., Braun, C., Dimyan, M. A., Ard, T., Mellinger, J., Caria, A., Soekadar, S., Fourkas, A. and Birbaumer, N., Think to move: a neuromagnetic brain-computer interface (BCI) system for chronic stroke, Stroke, Vol.39, No.3 (2008), pp.910-917.

Clancy, E. A. and Hogan, N., Relating agonist-antagonist electromyograms to joint torque during isometric, quasiisotonic, nonfatiguing contractions, IEEE Transactions on Biomedical Engineering, Vol.41, No.10 (1997), pp.10241028.

Halliday, D. M., Conway, B . A., Farmer, S. F. and Rosenberg, J. R., Using electroencephalography to study functional coupling between cortical activity and electromyograms during voluntary contractions in humans, Neuroscience Letters, Vol.241, Issue 1 (1998), pp.5-8.

Haykin, S., Adaptive filter theory, third ed., Upper Saddle River, NJ, Prentice-Hall(1996). 
Herr, H., Exoskeletons and orthoses: classification, design challenges and future directions, Journal of NeuroEngineering and Rehabilitation, Vol.6, No.21 (2009), pp.1-9.

Hochberg, L. R., Bacher, D., Jarosiewicz , B., Masse, N. Y., Simeral, J. D., Vogel, J., Haddadin, S., Liu, J., Cash, S. S., van der Smagt, P. and Donoghue, J. P., Reach and grasp by people with tetraplegia using a neurally controlled robotic arm, Nature, Vol.485 (2012), pp.372-375.

Ichijo, S. and Takahashi, K., EEG interpretation - 101 chapters, Igaku-Shoin Ltd. (2009) (in Japanese).

Japanese Ministry of Health, Labour and welfare social and assistance stations disorder ministry of health and welfare result of research on difficulty life in 2011 (nationwide home children with disabilities, and others Survey), (2013) (in Japanese).

Jolliffe, I. T., Principal component analysis. 2nd ed., Springer (2002).

Kiguchi, K. and Hayashi, Y., An EMG-based control for an upper-limb power-assist exoskeleton robot IEEE Transactions on Systems, Man, and Cybernetics Part B: Cybernetics, Vol.42, No.4 (2012), pp.1064-1071.

Kizuka, T., Masuda, T., Kiryu, T. and Sadoyama, T., Surface electromyogram, Society of Biomechanisms Japan ed., Tokyo Denki University Press (2008) (in Japanese).

McFarland, D. J., Miner, L. A., Vaughan, T. M. and Wolpaw, J. R., Mu and beta rhythm topographies during motor imagery and actual movements, Journal of Cerebral Function and Dynamics Brain Topography, Vol.12, No.3 (2000), pp.177-186.

Murray, S. A., Ha, K. H., Hartigan, C. and Goldfarb, M., An assistive control approach for a lower-limb exoskeleton to facilitate recovery of walking following stroke, IEEE Transactions on Neural Systems and Rehabilitation Engineering, Vol.23, No. 3 (2015), pp.441-449.

Nakanishi, Y., Yanagisawa, T., Shin, D., Fukuma, R., Chen, C., Kambara, H., Yoshimura, N., Hirata, M., Yoshimine, T. and Koike, Y., Prediction of three-dimensional arm trajectories based on ECoG signals recorded from human sensorimotor cortex, PLoS ONE, Vol.8, Issue 8 (2014), pp.1-9.

Pfurtscheller, G., Guger, C., Müller, G., Krausz, G. and Neuper, C., Brain oscillations control hand orthosis in a tetraplegic, Neuroscience Letters, Vol.292, Issue 3 (2000), pp.211-214.

Presacco, A., Goodman, R., Forrester, L. and Contreras-Vidal, J. L., Neural decoding of treadmill walking from noninvasive electroencephalographic signals, Journal of Neurophysiol. Vol.106(2011), pp.1875-1887.

Sankai, Y., HAL: hybrid assistive limb based on cybernics, The 13th International Symposium Robotics Research, Vol.66(2011), pp.25-34.

Schalk, G., Kubánek, J., Miller, K. J., Anderson, N. R., Leuthardt, E. C., Ojemann, J. G., Limbrick, D., Moran, D., Gerhard, L. A. and Wolpaw, J. R., Decoding two-dimensional movement trajectories using electrocorticographic signals in humans, Journal of Neural Engineering, Vol.4, No.3 (2007), pp.264-275.

Shindo, K., Kawashima, K., Ushiba, J., Ota, N., Ito, M., Ota, T., Kimura, A. and Liu, M., Effects of neurofeedback training with an electroencephalogram-based brain-computer interface for hand paralysis in patients with chronic stroke a preliminary case series study, Journal of Rehabilitation Medicine, Vol.43, Issue 10 (2011), pp.951-957.

Wolpawa, J. R., Birbaumer, N., McFarland, D. J., Pfurtscheller, G. and Vaughan, T. M., Brain computer interfaces for communication and control, Clinical Neurophysiology, Vol.113(2002), pp.767-791.

Zhu, C., Okada, Y., Yoshioka, M., Yamamoto, T., Yu, H., Yan, Y. and Duan, F., Power augmentation of upper extremity by using agonist electromyography signals only for extended admittance control, IEEJ Journal of Industry Applications, Vol.3, No.3 (2014), pp.260-269. 